\title{
Ruslands ontologiske sikkerhed
}

\section{Flemming Splidsboel Hansen}

\section{Ontologisk sikkerhed er sikkerhed for selvet. Begrebet anvendes i stigende grad om $\mathrm{fx}$ nationer, der tillægges behov for at føle sig sikre i deres respektive identiteter - og Rusland er på vej til- bage til en identitet, der bygger på mistro over for Vesten}

I den stadig mere intense debat om forholdet mellem Vesten og Rusland fokuserer vi næsten udelukkende på militær og økonomisk, herunder ikke mindst energimæssig, sikkerhed.

Der er dog et yderligere og meget akut sikkerhedsproblem i forholdet, og det er Ruslands søgen efter ontologisk sikkerhed. Her spiller Vesten en afgørende rolle ikke alene som Ruslands spejlbillede, men også som en samlet aktør, som med en blanding af dygtighed og held måske kan få Rusland til at føle sig sikker i en anden og mere positiv rolle end landets nuværende.

Ontologi er læren om det værende. Det handler således om det, 'som eksisterer', hvilket vil sige fysi- ske ting som træer og cykler såvel som luftige ideer som penge, religioner og nationer. Begrebet har primært været benyttet inden for psykologi og udviklingslære, og her betegner det individets forhold til selvet, dvs. det enkelte menneskes forhold til sin egen 'indre kerne' eller følelse af væren. Ontologisk sikkerhed er på den måde sikkerhed for selvet. Inden for de senere år er begrebet dog blevet løftet over det enkelte individ, og det bliver nu i stigende grad anvendt på grupper af individer, fx nationer. Disse fællesskaber tillægges altså nu det samme grundlæggende behov for at føle sig sikre i deres egne respektive identiteter, som også det enkelte menneske $g ø r$. 
For det enkelte individ grundlægges den stærke følelse af væren i de tidlige leveår, især via barnets primære omsorgspersoner, mens fællesskabet derimod løbende modtager sin følelse af væren i arv fra tidligere generationer. For såvel individet som for fællesskabet gælder herefter, at den ontologiske sikkerhed vedligeholdes i et konstant samspil med omgivelserne. Via dagligdagens bekræftelse af vaner, rutiner og gensidige roller skabes et stabilt og forudsigeligt miljø, hvor individet eller fællesskabet kan føle sig sikker på sig selv og sin egen identitet.

Den britiske sociolog Anthony Giddens forklarer, at manglen på ontologisk sikkerhed kan medføre, at det enkelte menneske kan have vanskeligt ved at se sin egen eksistens som et ubrudt forløb. Livet fremstår i stedet som en serie af separate episoder uden en rød tråd. Giddens tilføjer, at det er afgørende for fastholdelsen af selvet, at det enkelte menneske kan bevare en ubrudt fortælling om sin egen person; vi ved kun, hvem 'vi' er, hvis vi samtidig forstår, hvor 'vi' kommer fra, og hvor 'vi' er på vej hen.

Sikkerhedsteoretikeren Bill McSweeney sammenligner mangelen på ontologisk sikkerhed med den følelse, som ofrene for skjult kamera har. Her møder ofret en tilsyneladende bekendt og tryg situation, som hun er fortrolig med, og hvor hun også behersker sin egen rolle. I stedet udsættes hun for et tillids- brud, hvor andre ikke spiller de roller, som var forventet, og hvor hun derfor kastes ud i en helt ny rolle. Det er forvirringen og den akutte stress i den ukendte og utrygge situation, som skjult kamera er bygget på. Og det er det, som gør situationen ubehagelig for ofret.

\section{Det forkastede russiske selv}

Den russiske identitet har været udsat for dramatiske omfortolkninger i de seneste to årtier. Det startede i sovjetstyrets sidste leveår, men de rigtig store ændringer kom først efter Sovjetunionens sammenbrud. I et fuldstændigt brud med fortiden valgte den nye russiske ledelse under daværende præsident Boris Jeltsin at gøre Sovjetunionen til Ruslands såkaldte konstituerende anden, dvs. den direkte modsætning, som giver en aktør form og indhold.

De russiske politikeres ønske om at imitere Vesten og indføre et liberalt demokrati, en fri markeds $\varnothing$ konomi og et tæt fællesskab med Vesten var ikke alene begrundet $i$, at det var det 'rigtige' at gøre; det skyldtes også, at man derved kunne vende ryggen til det sovjetiske eksperiment. De tidlige reformpolitikere ønskede at fjerne Rusland så meget som overhovedet muligt fra Sovjetunionen.

I dag må vi sige, at deres ideer ikke rigtig slog igennem. Det skyldtes for det første den meget uheldige omstændighed, at de russiske 
vælgere valgte at forbinde den nye identitet med nogle af de mest negative følger af reformpolitikken. Magtmisbrug, korruption og socialt kollaps blev set som elementer af den nye identitet, som Kreml forsøgte at brede ud over landet. Og på den måde var den hurtigt dødsdømt.

Dertil kom, at mange i Rusland havde forventet at se flere imødekommelser fra Vestens side. Den officielle russiske fortælling var nu, at landet havde brudt med fortiden og var blevet som 'os'. Vores respektive roller og indbyrdes forhold skulle derfor ændres, på samme måde som det skete i forhold til fx Estland, Polen og Ungarn. Men den udvikling havde ikke det omfang og tempo, som russerne havde regnet med.

De blev ikke behandlet som et fuldgyldigt medlem af fællesskabet og det kunne heller ikke ske. 'De' var jo ikke som 'os', og vi kunne ikke lade som om, forholdene i Rusland var som her hos os, når de nu tydeligvis ikke var det.

Det betyder dog ikke, at vi ikke også har begået fejl. Øget opmærksomhed på dette spørgsmål kunne have fået os til i højere grad at acceptere, at Rusland fik lov at spille symbolske roller. Dem kunne vi så have bekræftet via vores handlinger, og på den måde kunne vi have bidraget til at skabe et eksternt miljø, som gik et skridt videre i retning af at understøtte den nye russiske identitet. I stedet skete der det, at russerne, primært pga. deres fejlagtige for- ventninger til de indbyrdes roller i deres forhold til Vesten, for ofte følte sig som offer for skjult kamera. De bristede illusioner udgør efter min mening en meget stor del af kilden til de nuværende spændinger mellem Rusland og Vesten.

Endelig er der det forhold, at identiteten var ny - den afløste altså noget andet. Denne anden identitet var sovjetisk, men den var mere end det. Igennem 2000'erne er den russiske befolkning blevet præsenteret for stadig flere elementer fra den sovjetiske politiske kultur, og generelt er de blevet meget varmt modtaget. Ved præsentationen af disse elementer - fx kollektivisme i stedet for 1990'ernes påståede indvidualisme har man understreget deres rod i den russiske kultur.

Den sovjetiske kultur var utvivlsomt baseret på den russiske kultur i en betydelig udstrækning, og det er en del af denne kultur, som nu er kommet tilbage til det politiske liv. Men den er kommet tilbage i en udvandet udgave, for det moderne Rusland er ikke Sovjetunionen, ligesom Sovjetunionen heller ikke var det førrevolutionære Rusland. Der sker jo konstant en læringsproces, hvor gamle normer forsvinder og andre bliver accepteret som 'de rigtige' i stedet. Men denne læring gik altså ikke så hurtigt, som Jeltsin håbede og måske endog forventede. Der var en del af det gamle tankegods, som ikke var klar til udskiftning endnu. 


\section{Ontologisk sikkerhed for Rusland}

Manglende ontologisk sikkerhed besværliggør et stabilt og forudsigeligt forhold mellem de involverede parter. Den berømte amerikanske psykolog Carl Rogers fortæller fx i en af sine bøger om en klient, som opsøgte ham pga. et svagt udviklet selv. Klienten havde levet sit liv efter andres krav og forventninger, og hun forklarede, at

"Jeg forsvarede ikke mine egne overbevisninger, og det har nået et punkt, hvor jeg ikke ved, om jeg har nogle overbevisninger at forsvare. Jeg har ikke været helt ærlig med at være mig selv eller faktisk vide, hvad mit rigtige selv er, og jeg har bare spillet sådan en slags falsk rolle".

Jeg skal ikke strække analogien for langt, men det kræver ikke megen fantasi at forestille sig Ruslands tidligere præsident og nuværende premierminister Vladimir Putin på terapeutens briks for, på Ruslands vegne, at få hjælp til et problem af samme type. Hvilken type stat er Rusland egentlig? Hvad er landets identitet? $\mathrm{Og}$, som en naturligvis forlængelse af svarene på disse to spørgsmål, hvad er Ruslands interesser?

Det stod i hvert tilfælde mere og mere klart, at Rusland ikke havde været helt ærlig over for hverken sig selv eller os. Rusland var ikke, hvad man hævdede, det var. Det havde i stedet en anden identitet og derfor også andre interesser. Landet havde, som Rogers' klient, spillet en slags falsk rolle. Og det var en rolle, som ikke fandt genklang i eller blev støttet af det russiske selv.

I denne falskhed ligger også en del af forklaringen på, at vi havde svært ved at anerkende den nye russiske identitet. Der var for meget 'papegøjesnak', dvs. en overfladisk retorik, som tydeligvis ikke modsvarede de bagvedliggende holdninger. Men som antydet var vores afvisning samtidig med til at skubbe mange russere væk fra dele af den ny identitet, som de ellers var klar til at acceptere som deres egne.

På samme måde som Rogers forsøgte at få sin klient til at finde sit eget selv og til at være tro mod det, så har Putin efterfølgende også ledt den russiske befolkning tilbage til en del af dens selv, som den er fortrolig med, og som derfor giver den tryghed. Det er muligvis en af Putins største bedrifter og en af forklaringerne på, hvorfor han nyder så stor popularitet i landet. Han har, for nu at formulere det lidt populært, givet den russiske befolkning psykoterapi efter de traumatiske oplevelser i 1990'erne.

Efterhånden som den russiske befolkning tog mere og mere afstand fra den ide, at Rusland skulle være en kopi af Vesten, så formulerede meningsdannere i landet i stedet en identitet, som i bund og grund bare var en afvisning af de samme værdier. Alt hvad Vesten var, ja, det var Rusland ikke. Bl.a. blev vores individualisme, liberalisme og påståede 
konsumerisme således afvist med dommen 'ikkerussiske værdier' (selvom den gennemsnitlige russer jo i virkeligheden fokuserer ganske meget på forbrug).

Putin har siden taget denne proces et skridt videre. Han har omformuleret de negative værdier, dvs. afvisningerne, til positive værdier. De 'ægte' russiske værdier er nu bl.a. kollektivisme, orden og spiritualitet (de to sidstnævnte som misforståede modsætninger til hhv. liberalisme og konsumerisme). Det er værdier, som i dag bliver fremmet under det nye slogan 'det suveræne demokrati'. Bag denne betegnelse ligger en semiofficiel ideologi, som hævder, at Rusland har ret til at indføre sin egen samfundsorden og i øvrigt helt uden vestlig indblanding. Det suveræne demokrati er derfor ikke alene et idesæt om de indre forhold i Rusland - det er tillige en afvisning af Vestens påståede politiske missionering. I disse tanker ligger derfor også et modsætningsforhold, hvor Vesten forsøger at spænde ben for Rusland og forhindre landet $i$ at finde tilbage til sit eget selv.

Som nævnt er det af stor betydning for den ontologiske sikkerhed, at man kan fastholde en ubrudt fortælling om sig selv. Men allerede nu betragter russerne i høj grad 1990'erne som et årti, hvor de var løsrevet fra deres sande identitet; de er nu ved at blive genforenet med nogle af værdierne fra den tidligere politiske kultur og dermed også med kernen af den tabte identitet. Man er tilbage i et velkendt spor.

\section{Rusland og Vesten}

Bagtæppet for den russiske identitetsdannelse har været mistro over for Vesten. Der var en ganske kort periode omkring Sovjetunionens sammenbrud, hvor denne mistro var vanskelig at få øje på, men den lå meget latent under overfladen. Allerede tidligt i 1992 begyndte de russiske medier således at berette om ellers provestlige politikere og kommentatorer, som have besluttet at konvertere tilbage til deres tidligere udenrigspolitiske overbevisninger. Som allerede nævnt skyldtes denne udvikling i en vis grad, hvad russerne så som manglende vilje i Vesten til at lade dem indtage deres nye rolle som en af 'os'.

Fx advarede en artikel på dette tidspunkt om, at de russiske meningsdannere var ved at forberede offentligheden på en kommende konflikt med Vesten. Baggrunden var den påståede russiske defaitisme og Vestens ydmygelse af landet. Det blev tilføjet, at den russiske befolkning ville være klar, når tidspunktet indtraf (Nezavisimaja gazeta, den 5. marts 1992). Det skulle jo senere vise sig at være en beklageligt præcis forudsigelse.

Den politiske ændring var ikke alene et resultat af uindfriede forventninger, følelser af afvisning og skuffelser. Der var også en god porti- 
on bevidst manipulation. Ifølge den russiske udenrigspolitiske forsker Dmitrij Trenin pressede det russiske forsvar tidligt på for at få dele af det politiske system til at fremmane en ekstern fjende. Årsagen var faldende bevillinger og prestige. Det russiske forsvar var blot en skygge af sit gamle sovjetiske selv (1992-forsvarsbudgettet udgjorde blot 20 pct. af niveauet for 1988), og det havde brug for at vise, at der stadig var alvorlige trusler mod landet.

Trenin forklarer, at forsvarets ønske blev indfriet af velvillige politikere. Oppositionen ønskede at fremstille det som om, Ruslands nye vestlige partnere var både svigagtige og aggressive, og at landets ledelse derfor arbejdede imod de nationale interesser. Snart måtte også Jeltsin og hans skiftende regeringer følge med for at vise, at de skam var kritiske over for Vesten, ligesom de også hurtigt så en interesse $\mathrm{i}$ at aflede vælgernes opmærksomhed fra de mange hjemlige problemer.

Resultatet af alt dette var, at Vesten, og i særdeleshed USA og NATO, blev udpeget som de nye - eller rettere, gamle og velkendte - fjender. Studier har vist, hvordan de russiske politikere meget effektivt overbeviste befolkningen om, at Vesten ønsker at holde Rusland nede ved at isolere og omringe landet og ved at bremse dets økonomiske vækst og forhindre det $\mathrm{i}$ at følge sin egen politiske kurs.

På denne måde kan politikerne overdrage nye værdier, interesser og mål til vælgerne. De får dem ganske enkelt til at forfølge præferencer, som de ikke havde før eller måske endda ikke engang havde tænkt over. Denne proces er markeret med rødt i litteraturen om demokratisering, for den sættes ofte i værk af skruppelløse politikere, som ønsker at skabe et modsætningsforhold mellem 'os' og 'dem'. 'De' kan fx være et etnisk mindretal eller en anden stat, og det er en form for dæmonisering, som især trives under svage politiske kulturer og medier. I Rusland blev processen lettet af den latente modstand mod Vesten, som allerede fandtes i landet, og den blev givet ekstra fart af de politisk kontrollerede og ukritiske medier. Den russiske befolkning ser naturligvis det uheldige i udviklingen. Alligevel har den siden midten af 1990'erne taget en række skridt i retning af at vende tilbage til et opslidende eller på længere sigt ligefrem ødelæggende forhold, hvor man retter kræfterne mod hinanden. Det virker naturligvis paradoksalt, men forklaringen kan være den enkle, at det negative forhold faktisk bidrager til en følelse af ontologisk sikkerhed. En artikel om konstruktionen af fjendebilleder i Rusland opsummerede det således meget rammende med titlen "Ich hasse, also bin ich" (Osteuropa, nr. 8, 2002).

I sikkerhedsteorien sammenligner man denne situation med den, som voldsramte kvinder ofte kan befinde 
sig i. Den enkelte kvinde vælger måske at blive i forholdet med sin partner, fordi hun har svært ved at se sig selv som et selvstændigt individ med egen identitet uden for forholdets velkendte og veldefinerende rammer. Forholdet er ikke godt for hende, men via det får hun sin identitet (fx fru bankdirektør Pedersen eller fru grosserer Nielsen), og det giver hende omgivelser, hvor hun er fortrolig med de vigtigste roller og forventningerne til disse. Alternativet kan være alt for usikkert og byde på for mange udfordringer, fordi rollerne er ukendte.

Som allerede antydet er mistroen over for Vesten, for nu at sætte det lidt på spidsen, den russiske default. For mange russere faldt brikkerne derfor på plads igen, da deres politikere forklarede, at Vesten i virkeligheden slet ikke ønsker, at Rusland skal komme sig efter Sovjetunionens sammenbrud. For dem er forholdet mellem de to parter én lang fortælling om Vestens frygt for og afvisning af den russiske kæmpe. De ser dette mønster gentaget nu, og de er overbeviste om, at Rusland er nødt til at hjælpe sig selv, og at genrejsningen vil ske på trods af Vesten.

\section{Mulige løsninger}

Der er ikke nogen let vej ud af denne situation. Teoretikere taler nogle gange om en fælles konstituerende anden, dvs. en aktør, som ikke er en del af den indbyrdes konflikt, men hvis handlinger kan få de stridende parter til at fokusere på deres ligheder snarere end på deres forskelligheder. Umiddelbart efter angrebet på USA den 11. september 2001 talte man om al-Qaeda som en mulig fælles konstituerende anden, men vi må konstatere, at truslen fra den internationale terrorisme endnu ikke har været stærk nok til rigtig at bringe Rusland og Vesten tættere på hinanden.

Det betyder, at vi i stedet må se i kassen med tillidsskabende foranstaltninger. Ansvaret hviler på begge parter, men det er nok mest realistisk, at Vesten tager det primære initiativ. Det skyldes simpelthen, at vi ontologisk er mest sikre. Sagt på en anden måde 'hviler' vi mere i vores identitet, og vi er derfor mindre fokuserede på at (re)definere vores identitet via forholdet til Rusland. For den russiske side berører forholdet derimod noget mere centralt det er en større del af deres væren, som er i spil.

Som et første skridt bør vi glide af på nogle af de konfrontationer, som Rusland eftersøger. Der er en tendens til, at vi i Vesten undervurderer vores styrke i forhold til Rusland. Som samlet aktør er vi dog så meget stærkere, at vi blot bør trække på skuldrene af nogle af de mest symbolske provokationer. I denne kategori finder vi $\mathrm{fx}$ flådeøvelsen mellem Rusland og Venezuela i december 2008 og de efterhånden rutinemæssige flyvninger ude over Nord- 
søen. Og måske skal sågar også den russiske trussel om opsætning af atommissiler i Kaliningrad henregnes til denne kategori. Nogen betydning ud over det symbolske har den i hvert tilfælde ikke.

Dette er ikke et råd om eftergivenhed. Vi bør stille klare og gerne skrappe krav til Rusland, men vi bør også vælge vores slagsmål med omhu. Hvis russiske meningsdannere $\varnothing n s k e r$ at overbevise befolkningen om, at Vesten gerne vil se Rusland i knæ, ja, så skal vi passe på ikke at bekræfte denne påstand. Det kan vi bl.a. gøre ved mere eller mindre at ignorere de mest symbolske provokationer. Deres vigtigste formål er at få os til at reagere på en måde, som synes at vise, at mistilliden til Rusland er intakt. Og efterfølgende bruges de til at styrke Ruslands ontologiske sikkerhed ved at definere landet som antivestligt.

På det mere praktiske plan kan vi fx invitere til et tættere militært samarbejde, til øget udveksling af både militære og civile studerende og til fælles forskningsmæssige og kulturelle aktiviteter. Et andet tiltag kan være at lempe visumreglerne, så snart det er forsvarligt; dette er et område, hvor mange russere og andre østeuropæere føler sig mistænkeliggjort og ydmyget, når de bliver taget til side i lufthavnen for at få foretaget helbredstjek, eller når unge kvinder går på det udenlandske konsulat uden make-up, fordi de frygter at blive set som prostituerede.

Medierne spiller naturligvis også en stor rolle, og deres dækning af Rusland er desværre ofte båret af stereotyper. Landet er så meget andet end store pelse, guldkæder og firehjulstrækkere og vodka, sygdom og forurening, men vi hører for sjældent om 'den almindelige russer'. Det er en skam, for selvom historien ikke er så spændende, så er det netop den almindelige russer, som tegner landets fremtid.

Vores mål skal være at svække den russiske fortælling om, at vi vil dem ondt. Dermed kan vi gøre os håb om at levere et alternativ til den antivestlige identitet, som er skabt i landet, og ultimativt kan vi håbe på, at de vil føle sig sikre i en identitet, som ikke er defineret ved dens påståede forskelle fra vores. Det vil kræve, at vi får overbevist begge parter om, at 'de' egentlig ikke er så meget anderledes end 'os'.

Flemming Splidsboel Hansen, ph.d. er forskningskoordinator på Forsvarsakademiet. 